\title{
STUDI KOMPARATIF MENURUT IMAM HANAFI DAN IMAM SYAFI'I TENTANG SHOLAT JAMAK DAN QASAR BAGI MUSAFIR
}

\author{
Siti Muslimah \\ Sahal Abidin \\ Universitas Nahdlatul Ulama Surakarta
}

\begin{abstract}
Abstrak
Penelitian ini bertujuan mengetahui perbandingan pendapat dalam pelaksanaan shalat Jamak dan Qasar bagi Musafir dalam pandangan Imam Hanafi dan Imam Syafii. Penelitian ini termasuk termasuk penelitian pustaka, yaitu penelitian yang obyek penelitian utama adalah buku- buku yang ada di perpustakaan, karena semua penggalian sumber data berasal dari perpustakaan. Hasil penelitian menunjukkan komparasi dua pendapat tersebut apabila seorang musafir berniat melakukan shalat jamak maka kecenderungan lebih kepada Imam Syafi'i, karena untuk melaksanakan rukshah shalat jamak bisa dilakukan tanpa harus di Arafah dan Muzdhalifah. Tanpa terikat dengan tempatnya. Jadi ketika seorang musafir melakukan perjalanan dengan niat dan tujuan yang baik, maka boleh melaksanakan shalat jamak. Apabila seorang musafir melaksanakan shalat qasar, Imam Syafi'i cenderung bebas untuk memilih antara melaksanakan ataupun menyempurnakan 4 rakaat.
\end{abstract}

Kata kunci: Salat, Qasar, Musafir

\section{Abstract}

This research aims to find out the comparison of opinions in the implementation of Plural and Qasar prayers for Musafir in the view of Imam Hanafi and Imam Shafii. This research includes literature research, which is research whose main research objects are books in the library, because all 
excavation of data sources comes from the library. The results showed the comparison of the two opinions if a traveler intends to perform plural prayer then the tendency is more to Imam Shafi'i, because to perform rukshah plural prayer can be done without having to in Arafat and Muzdhalifah. Without being tied to its place. So, when a traveler travels with good intentions and purposes, it is permissible to perform plural prayer. When a traveler performs qasar prayers, Imam Shafi'i tends to be free to choose between performing or perfecting 4 rakaat.

Keywords: Salat, Qasar, Musafir

\section{A. PENDAhULUAN}

Islam datang bersama seperangkat hukumnya begitu luas dan lengkap. Syari'ah berlaku sepanjang zaman dan bersifat elastic dalam menghadapi perubahan zaman. Sebagai hukum yang sempurna syari'ah mengacu pada pertimbangan yang maslahah yang dengannya fleksibilitas hukum Islam pada penekanan ijtihad dapat berjalan dengan mulus, oleh karenanya hukum Islam dapat beradaptasi dengan perubahan sosial. Pendapat ini dipegangi oleh Linan de Belefonds dan mayoritas kaum reformis seperti Subhi Mahmasani dan Al Syatibi. ${ }^{1}$

Hukum Islam menempati posisi yang paling penting di mana memiliki ruang lingkup dan tujuan yang jauh sekali, mengatur hubungan antara manusia dengan Allah, hubungan manusia dengan sesame juga manusia dengan alam sekitar, karena sesungguhnya hukum Islam ditinjau dari segi falsafahnya merupakan hukum yang berkembang dinamis, elastis dan fleksibel. ${ }^{2}$ Sebagai ajaran yang sempurna syari'ah Islam mengatur ketentuan hukum shalat secara luas, karena shalat sebagai salah satu bentuk ibadah yang diberikan kepada manusia. Allah memerintahkan shalat sebagai suatu kewajiban.

Manusia bukanlah malaikat dan tidak akan mungkin berubah menjadi malaikat, yang menghabiskan waktunya untuk bertasbih tanpa tiada henti. Jelas, manusia tidak akan mampu seperti malaikat, karena manusia itu

\footnotetext{
${ }^{1}$ Muhammad Kholid Massad, Islamic Legal Psilosophy, (New Delhi: International Islamic Publisher Delhi, 1989), hal 1- 2, 225- 236, Al- Syatibi, Al-Muwafaqat fi Usul Al- Ahkam.

${ }^{2}$ Hasbi Ash Shiddieqy, Falsafah Hukum Islam, cet 3, (Jakarta: PT. Bulan Bintang, 1988), hal.7
} 
disamping dilengkapi dengan roh yang halus, juga dibentuk dari jasad yang bersifat teguh dan guncang, membutuhkan makan dan minum, kadang lelah dan kadang tidur. Manusia diberi akal pikiran untuk memikirkan tuntutantuntutan kebutuhan hidupnya baik bersifat fisik maupun psikis. ${ }^{3}$ Oleh karena itu Allah mewajibkan manusia untuk beribadah sesuai dengan kemampuan mereka yang berbeda sehingga tidak membebaninya dan tidak meyiksanya sesuai dengan kemampuannya, sehingga ia benar-benar memenuhi eksistensi secara total. ${ }^{4}$

Hal ini dibuktikan dengan adanya keringanan-keringanan terhadap pelaksanaan sebagian ibadah pada situasi dan kondisi tertentu, mengurangi jumlah raka'at shalat atau lebih tepatnya meringkas jumlah rakaat salah dari empat menjadi dua yang kemudian disebut dengan qasar yang merupakan salah satu wujud dari keringanan Allah SWT yang diberikan kepada manusia.

Kekuasaan Allah yang telah menjadikan manusia berbeda- beda baik pikiran, hati maupun persepsinya, ini adalah suatu rahmat, karena perbedaan tersebut bukanlah hal yang berprinsip sehingga tidak akan mengakibatkan perpecahan dan perselisihan tetapi justru akan membuka cakrawala berfikir manusia dan ini berarti Allah memberikan kesempatan kepada manusia untuk berbeda pendapat, berbeda dalam meninjau suatu keputusan yang dianggap sesuai dengan kepentingan, kemaslahatan terhadap kondisi masyarakat yang berbeda-beda. ${ }^{5}$

Permasalahan shalat bagi musafir, para ulama berbeda-beda pendapatnya. Seperti Ulama Hanafiyah menanggapi bahwa shalat Qasar itu wajib 'ain atas tiap- tiap musafir dan hanya di tempat itulah dibolehkan jamak dan dilarang jamak dalam satu waktu antara dua shalat selain dari tempat tersebut. ${ }^{6}$ Sedangkan menurut Imam Syafi'i bahwa Shalat Qasar bukan wajib 'ain, melainkan hanya Rukhsah (dispensasi). Dan membolehkan Jamak antara dua dhuhur (dhuhur dan Ashar) dan Dua Isya (Maghrib dan Isya) baik jamak taqdim maupun jamak takhir, bagi musafir yang

${ }^{3}$ Muhammad Qutub, Konsep Ibadah dalam Membentuk generai Qur'ani, alih bahasa Abu Fahmi, cet 2 (Jakarta: Gema Insani Press, 1992) hlm. 14-15.

${ }^{4} \mathrm{Ibid}$, hal 18

5 Yusuf Qardawi, dasar Pemikiran Hukum Islam, Taqwa, Ijtihad. Alih bahasa Husein Muhammad (Jakarta: Pustaka Firdaus, 1987) hal. 6.

${ }^{6}$ Syaikh Mahmoud Syaltout, et.al, Perbandingan Mazhab dalam masalah fiqih, alih bahasa Ismuha, cet 8 (Jakarta: Bulan Bintang, 1996) hal 79. 
mempunyai rukhsah qasar. ${ }^{7}$ Perbedaan ini muncul sebagai akibat metode penetapan hukum (istinbat hukum) yang berbeda-beda atau pola pikir mereka yang tidak sama.

Ada ketentuan mengenai pelaksanaan shalat yang berlaku khusus sebagai keinginan bagi yang sedang musafir, yakni mereka dibenarkan melakukannya dengan cara jamak atau qasar sebab suasana perjalanan selalu mengandung berbagai kesulitan, keringanan ini diberikan sesuai dengan salah satu prinsip hukum Islam meniadakan kesulitan. ${ }^{8}$

Islam mensyariatkan Shalat Jamak dan Qasar di dalam safar, karena di dalamnya terkandung hikmah- hikmah yang sangat dikehendaki untuk kemaslahatan umat. Seorang musafir di dalam safarnya, karena di dalamnya terkandung hikmah- hikmah yang sangat dikehendaki untuk kemaslahatan umat. Seorang musafir di dalam safarnya, akan ada kemungkinan menghadapi kesukaran dan keletihan. Hal ini memang perlu dicermati sebab bagaimanapun ibadah shalat menempati kedudukan yang penting dan utama dalam agama Islam. Perintah shalat tidak dapat ditinggalkan, perintah ini berbeda dengan perintah lainnya, dimana perintah shalat diterima langsung oleh Rasulullah di Sidratul Muntaha pada saat menghadap Allah. Dilihat dari prosedurnya penyampaian diperintahkannya shalat mempunyai kedudukan yang istimewa. ${ }^{9}$

Nama Lengkap Imam Hanafi adalah Nu'man ibn sabit Zautha Ibn Mah. ${ }^{10}$ Beliau keturunan bangsa persi (Kabul Afganistan), tetapi sebelum beliau dilahirkan, Ayah beliau pindah ke Kufah. Dengan demikian beliau bukan keturunan bangsa Arab asli, tetapi dari bangsa 'Ajam yaitu Bangsa Arab. ${ }^{11}$

Kakek Imam Hanafi adalah Zautha yang berasal dari Kabul, ia seorang tawanan perang, dia berperang melawan Usman bin Affan sewaktu menaklukkan Persia, Khurasan dan Afganistan. Setelah masuk Islam dia dibebaskan dan kemudian Menetap di Kufah sambil nerdagang kain sutra

${ }^{7}$ ibid, hal 79.

${ }^{8}$ Lahmudin Nasution, Fiqih Ibadah, cet II (Jakarta: Logos Wacana Ilmu, 1999) hal. 122.

${ }^{9}$ Hasbi Ash Shiddieqy, Pedoman Shalat, cet I, (Jakarta: Bulan Bintang, 1958) hal 44.

10 Muhammad Abu Zahrah, Abu Hanafiyah Hayatuhu wa Asruhu Arquhu wa Fiqhuhu, (tt, Dar al- Fikr al- Arabi, 1943), hlm 12. 50.

${ }^{11}$ Bahri ghazali dan Djumadris, Perbandingan Mahzab, (Jakarta: Pedoman Ilmi Jaya,1996), hlm 
sampai terlahir anak yang diberi nama sabit yaitu anak dari Hanafi. ${ }^{12}$ Imam Hanafi adalah panggilan dari Nu'man Ibnu Sabit zautha ibnu ah. Dipanggil Abu Hanifah karena anaknya Hanafi, juga karena beliau rajin beribadah kepada Allah, hal ini sebagai gelar yang berarti hamba Allah yang taat. Prinsip beliau tidak mudah digoyangkan, ini terlihat ketika akan diangkat menjadi pembesar tetapi dengan syarat beliau harus meninggalkan prinsipprinsipnya dalam hal ini Imam Hanafi lebih baik dipenjara daripada harus meninggalkan prinsip. Hanafi sendri dalam bahasa Iraq berarti tinta, jadi Abu Hanafi berarti Bapak Tinta, hal ini karena beliau paling cinta akan menulis, sehingga ia dipanggil teman-temannya dengan panggilan Abu Hanafi. ${ }^{13}$

Imam Hanafi pada mulanya mempelajari ilmu pengetahuan tentang hukum keagamaan, kemudian beliau pindah mempelajari ilmu kalam, menurut beliau ilmu kalam adalah satu-satunya ilmu pengetahuan yang paling tinggi dan amat besar gunanya dalam lingkungan, ilmu inilah termasuk dalam bagian pokok-pokok agama (ushulddin). ${ }^{14}$ Adapun guruguru beliau adalah para ulama tabi'in dan golongan tabi'it tabi'in, dari golongan tabi'in adalah Imam Atabi'in Abi Rabah (W.114H) Imam Nafi' Maula Ibn Umar (W.117 H) dan Imam Hammad bin Abu Sulaiman yang merupakan gurunya dalam bidang fiqh yang wafat tahun $120 \mathrm{H}$. Sedangkan guru beliau dari golongan tabi'it tabi'in adalah Imam Muhammad al-Baqir, Imam Ady bin Sabit, Imam Abdurrahman bin Harmaz, Imam Amr bin Dinar, Imam Mansur bin Mu'tamir, Imam Syu'ban bin Hajjaj, Imam 'Asim bin Abi Najwad, Imam Salamah bin Kuhail, Imam Qatadah bin Imam Rabi’ah bin Abi Abdurrrahman. ${ }^{15}$

Beliau adalah putra seorang pedagang kain terkenal di Kufah, sehingga sejak muda telah terdidik dalam urusan perdagangan, dan hidup berkecukupan. Tetapi beliau tetap dermawan, suka membantu kepada orang yang menderita dan membutuhkan ${ }^{16}$. Dengan demikian didukung keadaan ekonomi yang memadai, beliau tidak segan-segan mencurahkan tenaga, pikiran dan hartanya untuk membiayai aktifitas-aktifitas yang ada

${ }^{12}$ Moenawar Chalil, Biografi Empat Serangkai Imam Mazhab, cet 7, (Jakarta: Bulan Bintang, 1990), hlm19.

${ }^{13} \mathrm{Ibid}, \mathrm{hlm} 19$.

${ }^{14} \mathrm{I}$ Ibid, hlm 27.

${ }^{15}$ Ibid, hlm 23

${ }^{16}$ Ibid, hlm 24 
hubungannya dengan pengetahuan, beliau sejak kecil telah menggemari terutama pengetahuan yang berhubungan dengan hukum-hukum agama Islam, setelah Imam Hammad bin Abi Sulaiman wafat, beliau menggantikannya sebagai guru, sehingga pada masa itu namanya terkenal ke seluruh Persia, banyak para murid gurunya yang datang belajar padanya. ${ }^{17}$

Karena kepandaian Imam Hanafi dalam segala hal, maka para pembesar muslimin sepakat untuk mengangkat beliau menduduki kursi mufti menggantikan Imam Ibrahim an-Nakha'i yang wafat, tentu saja pengangkatan itu atas dukungan pembesar negeri, maka sejak itu yang hendak meminta keputusan hukum atau fatwa hukum, mereka datang di hadapan beliau. ${ }^{18}$

Murid-murid Imam Hanafi sangat banyak jumlahnya, diantaranya yang terkenal adalah Abu Yusuf Yaqub bin Ibrahim al-Ansari, Imam Muhammad bin Hasan bin Frqad asy-Syaibani, Imam Zafar bin Muzail alKufi, dan Imam Hasan bin Ziyad al-Lu'lu'i. Beliau dalam mengajar muridnya tidaklah disuruh mengikuti perkataan dan pendapatnya, tetapi mereka diberi kebebasan dalam berfikir. ${ }^{19}$

Walaupun Imam Hanafi tidak banyak mengarang untuk mazhabnya, namun mazhabnya tetap terkenal disebabkan murid-muridnya atau anak adiknya yang banyak menulis kitab untuk mazhabnya ${ }^{20}$. Sedangkan cara memberikan pelajaran kepada murid-muridnya Imam Hanafi memberikan pada yang telah dewasa, mereka tidak disuruh mengikuti pendapat-pendapat beliau, tetapi disuruh /diperintah supaya menjadi orang yang berfikir merdeka, berpendapat leluasa dari segala kungkungan dan jeratan yang kiranya akan mengikat kecerdasan otak mereka juga agar mereka menyelidiki dan membahas hukum-hukum agama dengan sebaik-baiknya dengan arti kata yang sebenarnya mengikuti pimpinan Allah dan Rasulnya. Lebih lanjut Muhammad Ibn Hasan pernah meriwayatkan bahwa Imam Hanafi seringkali bemunadarah, bermujadalah, bertukar pikiran dengan para muridnya atau dengan para sahabat beliau yang terdekat tentang soal-soal hukum secara merdeka, dan para murid beliau pun membantahnya dan

${ }^{17}$ Ahmad Asy- Syubasi, Sejarah dan Biografi Empat Mazhab, alih bahasa: Sabil Huda, (Jakarta: Bumi Aksara,1991) hlm 18

${ }^{18}$ Moenawar Chalil, Op. cit., hlm 31.

${ }^{19} \mathrm{Ibid}$, hlm 34.

${ }^{20}$ Ahmad Asy-Syubasi, Op.Cit., hlm. 19 
menolak alasan-alasan yang dikemukakan beliau. ${ }^{21}$

Pada tahun $132 \mathrm{H}$ kekerasan bani Umayyah digulingkan oleh bani Abbasiyah. Kholifah bani Abbasiyah yang pertama meninggal dunia dan digantikan saudaranya Al Mansur, selain membasmi terhadap keturunan Bani Umayyah, Al Mansur mulai mencurahkan kebencian terhadap Ahl Bait. Pada tahun $145 \mathrm{H}$ para pengikut Muhammad Natsh Zakiyah melakukan perlawanan terhadap Al Mansur. Lalu Ibrahim saudaranya melanjutkan perjuangan Muhammad Al Natsh. Imam Hanafi mendukung Ibrahim karena keadilannya. Tidak lama kemudian Ibrahim dikalahkan Al Mansur tahun 146H, Khalifah mulai menangkap para pendukung Ibrahim, salah seorang dari mereka adalah Imam Hanafi. Namun ketika dibawa ke pengadilan, para pejabat istananya mengetahui dan menghormatinya, lalu Abu Hanafi dibawa ke hadapan Kholifah Al Mansur seraya berkata "orang itu adalah ulama besar masa kini” setelah Al Mansur mendengar perkataan Abu Hanafi dan menyadari betapa alimnya beliau, lalu kholifah menawarkan kedudukan sebagai qadi (hakim). Imam Hanafi menolak penawaran itu seraya berucap "jabatan hakim tidak cocok untukku" Al-Mansur menjadi marah dan berteriak "engkau pembohong!" Imam Hanafi menjawab dengan tangkas "apabila aku dianggap pembohong, maka jelaslah tadi bahwa aku tidak cocok menduduki kedudukan hakim", karena pembohong tidak boleh diangkat sebagai hakim". Dengan nada marah, Al Mansur berkata dengan tegas bahwa Khalifah tetap berkeinginan Abu Hanifah menduduki jabatan itu, namun demikian Imam Hanafi berani menjelaskan bahwa dirinya tetap tidak menerimanya. Imam Hanafi begitu sadar bahwa masa depan fiqih harus bebas dari kalangan penguasa, sebab hanya dengan menghindari ikatan kedudukan ia dapat leluasa mengembangkan kajian-kajian fiqihnya, itulah sebabnya memperjuangkan kebebasan bependapat dengan segala kekuatan yang dimilikinya. ${ }^{22}$

Imam Hanafi adalah seorang yang suka memberi kebebasan untuk berfikir, hal ini terbukti pada cara-cara beliau mengajar mereka (muridmurid Imam Hanafi) diberi kebebasan untuk berfikir dan berpendapat mereka juga diberi kepercayaan untuk memecahkan masalah-masalah baru yang belum didapat dalilnya dan mereka dilarang bertaqlid kepadanya.

\footnotetext{
${ }^{21}$ Moenawar Cholil, Op. Cit., hlm 37

${ }_{22}$ Mu'min A Sirri, Sejarah Fiqh Islam, Sebuah Pengantar, Cet II, (Surabaya: Risalah Gusti,1996), hlm 85
} 
Diskusi (tukar pikiran) adalah hal yang sering dilakukan Imam Hanafi beserta muridnya dan mereka diberi kebebasan membantah dan menolak alasan-alasan yang dikemukakan beliau. ${ }^{23}$ Oleh karenanya beliau terkenal sebagai seorang imam ahli Ra'yi dn Qias, tetapi mengerti tentang hadishadis yang telah diterima riwayatnya pada masa itu. ${ }^{24}$

Dalam hukum beliau sangat hati-hati, kaidah-kaidah umum bagi istidlal Imam Hanafi sebagaimana ditulis al-Khatib al-Baghdadi dalam tarikhnya yang dikutip oleh Hasbi Ash-shidiqie bahwa Imam Hanafi berkata:

Saya mengambil kepada kitab- kitab Allah, maka apa yang tidak saya ketemukan didalamnya maka saya ambil dari sunnah Rasulullah jika tidak saya ketemukan didalam kitab Allah dan sunnha Rasulullah niscaya saya akan mengambil pendapat pendapat sahabatnya saya ambil perkataanyang saya kehendaki dan saya tinggalkan perkataan-perkataan yang saya kehendaki dan saya tak keluar dari pendapat mereka kepada pendapat orang lain dan mereka. Adapun apabla setelah sampai urutan itu atau telah datang kepada Ibrahim, Asy-Syabl, Ibnu Sirin, al-Hasan, Atha', Said dan Abu Hanafi menyebutkan beberapa orang lagi sebagaimana mereka telah berijtihad. ${ }^{25}$

Selanjutnya Hasbi mengutip al-Intiqo' yang menerangkan bahwa Imam Hanafi sebagai berikut:

Pendirian Imam Hanafi, ialah mengambil kepercayaan dan berlari dari keburukan memperhatikan muamalah- muamalah manusia dan apa yang telah mendatangkan maslahah bagi urusan mereka. Beliau menjelaskan urusan atas Qiyas. Apabila Qiyas tidak baik dilakukan beliau melakukan istihsan selama dapat dilakukannya. Apabila tidak dilakukannya maka beliaupun kembali kepada 'urf masyarakat dan mengamalkan hadist yang telah terkenal dan yang telah di ijma'i para ulama, kemudian beliau mengqiyaskan sesuatau kepada hadits itu selama qiyas itu masih dapat dilakukan, kemudian beliau kembali kepada istihsan, yang diantara keduanya yang lebih tepat, kembalilah beliau kepadanya.26

Berdasarkan uraian di atas maka terjadi pokok-pokok pegangan ulama hanafiyah beristidlal dan beristinbat adalah sebagai berikut:

\footnotetext{
${ }^{23}$ Moenawwar Cholil, Op. Cit., hlm 77-78

${ }^{24}$ Ibid, hlm 57.

${ }^{25}$ Hasby Ash- Shidieqy, Op. Cit., hlm 134

${ }^{26} \mathrm{Ibid}, \mathrm{hlm} 135$
} 
1. Al Kitab (Al-Qur'an), yang merupakan tiang atau dasar umum syariat sebagai referensi umum bagi hukum-hukum syariat sekaligus sebagai sumber Islam.

2. As-Sunnah, sebagai sumber hukum kedua setelah Al-Qur'an, AsSunnah berfungsi sebagai penguat dan penjelas (pemerinci) bagi ayat- ayat Al-Quran yang masih global, disamping juga menetapkan perkara yang belum ada ketentuannya dalam AlQur'an.

Dalam menerima riwayat suatu hadis beliau membuat syarat yang berat, yaitu:

a. Harus diriwayatkan oleh orang banyak (mutawatir).

b. Telah diamalkan oleh ahli fiqh ternama.

c. Diriwayatkan oleh seorang sahabat dihadapan sahabat yang banyak dan tidak seorangpun yang menyangkal riwayat itu.

Karena syarat yang demikian berat, maka beliau membuka kemungkinan menjadikan qiyas dan ihtisan sebagai dasar hujjah yang seluas-luasnya. Sehingga golongan itu masyhur sebagai ahli ro'yi dan qiyas. ${ }^{27}$ Adapun metode pengambilan hukum mereka (ulama Hanafiyah ) mengacu pada ketetapan-ketetapan berikut :

a. Petunjuk lafadz yang umumnya adaah qath'i sebelum di takhsiskan.

b. Larangan (Nahi) tidak mengakibatkan batalnya pekerjaan yang dilarang.

c. Mafhum Mukhalafah tidak dapat dijadikan Hujjah.

d. Mutlak dan muqayyad berbeda, sebagai keduanya memiliki dalalah sendiri. ${ }^{28}$

3. Fatwa Sahabat, karena merekalah orang-orang yang menyampaikan risalah dan mereka pulalah yang memperhatikan proses turunya wahyu. Para sahabat adalah orang- orang yang membawa ilmu-ilmu

${ }^{27}$ Direktorat Pembinan Perguruan Tinggi Agama/ IAIN, Pengantar Ilmu Fiqh (Pengantar Ilmu Hukum Islam), (Jakarta: t.p 1981) hlm 78.

${ }^{28}$ Ibid., 
rasul kepada generasi sesudahnya. Fatwa sahabat itu tidak diperoleh dari ijtihad semata, tetapi kebanyakn didapat dari perkataan Rasul sekalipun mereka tidak meriwayatkan sabda- sabda tersebut. Abu bakar, Umar dan Ali tidak meriwayatkan hadis dari Nabi padahal mereka lama berkumpul dengan beliau, sudah barang tentu mereka berfatwa berdasarkan sabda-sabda Rasul tanpa menyandarkan fatwanya kepada beliau sebab mereka takut kepada Rasul. Mereka tidak mengambil fatwa Tabi'in karena mereka menganggap Tabi'in adalah sama dengan mereka yang boleh berfikir dan berpendapat.

4. Qiyas, Imam Hanafi menerima Qiyas sela tidak dapat nas dalam AlQur'an dan As- Sunnah, juga tidak menunjukkan fatwa atau perkataan sahabat. Sedang yang dimaksud Qiyas adalah menyamakan masalah yang tidak ada nas hukumnya dengan masalah yang ada dasar hukumnya, karena adanya persamaan 'illat (alasan) pada masalah tersebut. Pada dasarnya Qiyas merupakan pengembangan hukum terhadap nas. Imam Hanafi menggunakan Qiyas secara luas dalam istinbat hukumya. Ia mencari 'illat dan apabila menemukannya kemudian mengujinya. Imam Hanafi juga sering memprediksi peristiwa- peristiwa yang belum terjadi untuk ditentukan hukumnya, apabila 'illatnya sama terhadap dalam nas fiqih, semacam ini dinamakan Fiqh Taqdir yang kemudian menjdai satu ciri Fiqih Hanafiyyah.

5. Ihtisan. Hukum yang menyimpang dari kaidah yang berlaku karena ada faktor lain yang mendorong agar keluar dari ketertarikannya dengan kaidah itu, yang dipandang justru akan lebih dekan dengan tujuan syara'. ${ }^{29}$ Sebagaimana bahwa pengambilan dalil dari sumbernya, haruslah secara berurutan sesuai dengan kekuatan hujjah dan martabatnya. Dalam konteks istihsan maka digunakan setelah dalam Al-Qur'an, Hadis, Fatwa para sahabat dan Qiyas tidak juga ditentukan hukumnya. Ulama Hanafiyyah berbpendapat bahwa nasnas hukum pasti memiliki 'illat hukum itu sendiri, sehungga ada petunjuk (dalil) yang menentukan lain. ${ }^{30}$ Seperti telah disinggung

${ }^{29}$ Definisi tersebut menurut Abu al- Hasan, al- kharkhi, yang dikutip oleh M. Abu Zahrah dalam usul al- fiqh, HI, hlm 401

${ }^{30} \mathrm{Ibid}, \mathrm{hlm} 365$. 
bahwa ulama Hanafiyyah membuka seluas-luasnya kemungkinan qiyas dan ihtisan.

Oleh karena setiap nas hukum memiliki 'illat dan ihtisan didefinisikan diktum yang menyimpang dari kaidah yang berlaku karena ada faktor lain yang mendorong dari ketertarikannya dengan kaidah tersebut. Dipandang justru akan lebih dekat dengan tujuan syara'. Maka istihsan ini tentunya berupa penyimpangan dari qiyas (zahir) kepada hukum lain yang bertentangan. Dan ini terjadi karena ada beberapa kemungkinan antara lain :

a. Berdasarkan penelitian, qiyas zahir tidak layak diterapkan pada suatu kasus, kemudian mujtahid tersebut mencari 'illat yang lain, dalam hal ini qiyas zahir berpindah ke qiyas hafi. Qiyas Zahir bertentangan dengan nas oleh sebab itu qiyas ditinggalkan dan nas itulah yang diamalkan, sebab qiyas itu dipergunakan selama tidak ada nas.

b. Qiyas itu bertentangan dengan ijma' dalam kasus seperti ini maka qiyas ditinggalkan dan dipakailah ijma' atau 'urf.

6. Ijma' yaitu kesepakatan seluruh Mujtahid pada suatu masa tertentu terhadap suatu hukum. Ulama sepakat ijma' dapat dijadikan sebagai hujjah.

7. 'Urf yaitu dimaksudkan dengan 'urf adalah kebiasaan yang dilakukan oleh ummat Islam yang tidak ada ketentuannya dalam nas, sunnah atau perbuatan sahabat. 'Urf ini dibagi menjadi dua macam:

a. 'Urf yang sah (benar) yaitu 'urf yang tidak bertentangan dengan nas dan 'urf ini dibagi dua yaitu 'urf 'amm (umum) dan 'urf khas (khusus) menurut ulama Hanafiyah 'urf 'aam ini dapat mengalahan qiyas kemudian dinamakan istihsan.

b. 'Urf yang fasid, 'urf yang tidak bisa dijadikan hujjah. ${ }^{31}$

Betapapun Imam Hanafi terkenal dengan mazhab yang rasionalis acap kali menyelami arti-arti 'illat suatu hukum serta sering menggunkan qiyas. Tetapi itu tidak berarti beliau menyebarkan nas-nas Al-Qur'an atau meninggalkan hadis dan atsar. Tidak ada riwayat sahih yang menyebutkan

\footnotetext{
${ }^{31}$ M. Abu Zahrah, Op. Cit., hlm 176-178.
} 
bahwa Imam Hanafi mendahulukan rasio daripada sunnah atau atsar. Bahkan kalau beliau mendapatkan atau menemukan pendapat atau qaul (pernyataan) sahabat yang benar, ia menilak dan melakukan ijtihad. Secara faktual, pemikiran fiqh Imam Hanafi memang sangat mendalam dan rasional. Ia memberi syarat ketat dan selektif dalam penerimaan hadis ahad. Sikapnya ini sebenarnya dimaksudkan untuk mengukuhkan kebenaran periwayatan hadis. Apabila ia memenuhi syarat hadis itu tidak dapat dijadikan dalil dari suatu hukum.

Bagi Imam Hanafi ada tiga syarat yang harus dipenuhi dalam penerimaan hadis ahad, di antaranya:

1. Orang yang meriwayatkan tidak boleh berbuat atau berfatwa yang bertentangan dengan hadis yang diriwayatkan.

2. Hadis ahad tidak boleh menyangkut persoalan umum dan sering terjadi, sebab jika menyangkut persoalan umum dan sering terjadi, mestinya hadis itu diriwayatkan oleh banyak perawi, tidak seorang saja.

3. Hadis ahad tidak bertentangan dengan kaidah-kaidah umum atau dasardasar kulliyah (mabadi' kulliyah).

Selain persyaratan di atas, dalam banyak hal Imam Hanafi lebih mengutamakan hadis yang diriwayatkan oleh fuqaha dari pada seorang ahli hadis, apalagi yang menyangkut hukum. Karenya memprioritaskan hadis yang diriwayatkan oleh orang-orang yang mengerti masalah fiqhiyah. ${ }^{32}$

Dalam menetapkan hukum, Imam Hanafi dipengaruhi oleh perkembangan hukum di Kuffah, yang terletak jauh dari kota madinah sebagai tempat tinggal Rasulullah yang banyak didapati hadis. Di kuffah kurang perbendaharaan hadis, di samping di Kuffah sebagai kota yang berada di tengah kebudayaan Persia, kondisi kemasyarakatannya telah mencapai tingkat peradaban cukup tinggi oleh karenanya banyak muncul problema kemasyaratan yang memerlukan penerapan hukumnya, karena problem itu belum pernah terjadi pada zaman Nabi atau zaman para sahabat dan tabi'i. maka untuk menghadapinya memerlukan ijtihad atau ra'yi. Hal itulah yang menjadi penyebab perkembangan pemikiran hukum di kuffah (Irak) dengan di madinah (Hijaz). Ulama di Madinah banyak menggunkan sunnah untuk menyelesaikan problema-problema yang muncul dalam

\footnotetext{
${ }^{32}$ Munim A Sirri, Op.Cit., hlm 89.
} 
masyarakat, sedangkan di kuffah sunnah hanya sedikit yang diketahui disamping banyak pemalsuan hadis.

Para ahli hukum di Kuffah (Irak) merumuskan hukum mereka dari pendapat- pendapat dan pertimbangan sahabat, seperti Ali, Abdillah bin Mas'ud dan para Tabi'in seperti al- Qamamah, al-Aswad Ibrahim anNakha'I dan lain lain.

Pemikiran para ahli hukum yang terdahulu dari pakar hukum sezamannya dalam mengambil keputusan kemudian beliau melakukan ijtihad dengan tetap memelihara semangat dan praktik yang berlaku di Kufah. Ketika itu, metode Abu Hanifah pengaruhnya besar dan simbol kristalisasi dalam tradisi Irak. ${ }^{33}$

Melihat perkembangan sejarah-sejarah yang terus bergulir dan perubahan zaman yang terus berubah dan masyarakatnya terus mengalami perubahan, maka sejak awal tokoh-tokoh mazhab telah melakukan ijtihad sesuai dengan situasi dan kondisi ketika itu Imam Hanafi menolak sebagian hadis yang diragukan kesahihannya dan hanya bertumpu pada Al-Qur'an. Melalui qiyas berusaha agar ayat-ayat Al-Qur'an dan disesuaikan dengan kondisi, mazhab Hanafi menggambarkan upaya menyesuaikan hukum Islam (fiqh) dengan kebutuhan masyarakat disegala bidang. ${ }^{34}$

Karena mazhab itu berdasarkan pada Al-Qur'an, hadist, ijma dan qiyas juga ihtihsan, maka bidang-bidang ijtihad menjadi luas sehingga suatu ketentuan hukum-hukum dapat disesuaikan dengan keadaan masyarakat tanpa keluar dari prinsip-prinsip dan aturan pokok Islam.

\section{B. METODE PENELITIAN}

Penelitian ini termasuk termasuk penelitian pustaka, yaitu penelitian yang obyek penelitian utama adalah buku- buku yang ada di perpustakaan, karena semua penggalian sumber data berasal dari perpustakaan. Sifat penelitian ini adalah diskriptif-analitik, yaitu memberikan gambaran secara jelas menyangkut hal- hal yang berkaitan khususnya mengenai hukum Shalat Jamak dan Qasar bagi musafir menurut pandangan Imam Hanafi dan Imam

\footnotetext{
${ }^{33}$ Huzaemah Tahida Yanggo, pengantar Perbandingan Mahzab, (Jakarta: t.p, 1997) hlm. 100.

${ }^{34}$ Ibid.
} 
Syafi'i juga menganalisa kedua pendapat ulama imam tersebut.

\section{HASIL DAN PEMBAHASAN}

\section{Analisis Shalat Jamak dan Qasar Bagi Musafir Menurut Imam Hanafi}

Imam Hanafi dalam menghukumi Jamak ialah tidak diperbolehkan kecuali, ketika melaksanakan haji yakni sedang di berada di Arafah dan saat bermalam di Muzdhalifah. Selain kedua tempat tersebut tidak diperbolehkan untuk melaksanakan sholat jamak meskipun sedang dalam perjalanan atau ketika berada di tempat domisili.

Berbeda dengan lagi ketika menghukumi shalat qasar, Imam Hanafi menghukumniya fardhu 'ain dan tidak boleh mengerjakan shalat dengan sempurna ketika dalam perjalanan. Konsep Imam Hanafi berbeda dengan Imam yang lain, bahwa Niat qasar tidak harus dilakukan bersamaan dengan takbiratul ihram, bahkan qasar tidak wajib diniati. Hal ini disebabkan karena musafir wajib menyengaja pada tujuan tertentu.

Dibolehkannya untuk melakukan qasar apabila tempat tujuan kirakira 3 marhalah $(121,5 \mathrm{~km})$ dan status musafir tersebut akan terlepas apabila bermukim selama 15 hari. Secara otomatis sholat yang dikerjakan wajib diqasar bukan itmam (sempurna).

Apabila sudah mencapai 3 marhalah tetapi tidak mengqasar shalatnya, maka aka nada beberapa perincian hukum salah satunya, shalatnya yang sempurna tidak sah. Dan setelah dua raka'at tidak melakukan duduk dalam waktu yang cukup untuk tasyahud dan sah sholatnya yang sempurna meskipun itu makruh. Dan apabila setelah dua raka'at melakukan duduk dalam waktu yang cukup untuk tasyahud, maka dua raka'at yang awal dihukumi shalat fardhu dan 2 raka'at yang kedua menjadi shalat sunnah mutlak (tidak terikat dengan waktu).

\section{Analisis Sholat Jamak dan Qasar bagi Musafir Menurut Imam Syafi'i}

Melakukan Shalat jamak menurut Imam Syafi'i memperbolehkan dengan ketentuan sama untuk bisa melaksanakan shalat qasar. Yang menjadi dasar pendapat ini adalah terdapat hadis yang menceritakan 
bahwa Nabi Muhammad SAW pernah melakukan shalat jamak bagi jamak taqdim/jamak ta'khir. Dibolehkannya mnelakukan shalat jamak apabila telah mencapai jarak kira-kira $81 \mathrm{~km}$ (2 marhalah). Beliau juga memperbolehkan melakukan jamak apabila disaat hujan tetapi dengan memenuhi persyaratan yaitu jamak taqdim. Tidak diperbolehkan melakukan Sholat Jamak apabila melakukan perjalanan tetapi tedapat unsur maksiat maka semua shalatnya dihukumi tidak sah.

Hukum Qasar menurut Imam Syafi'i ialah Sunnah dan apabila musafir berkenan untuk menyempurnakan shalatnya maka itu lebih baik atau lebih utama. Qasar bisa dilakukan apabila sudah mencapai jarak kira-kira 88,656 km atau 16 farsakh. Apabila musafir yang berdomisili di suatu tempat dan tidak berniat untuk muqim maka tetap diperbolehkan melakukan qasar selama 4 hari 4 malam. Dan jika musafir berniat untuk muqim maka tetap diperbolehkan selama 18 hari 18 malam.

\section{Analisis Komparatif Sholat Jamak dan Qasar Menurut Imam Hanafi dan Imam Syafi'i}

Dari dua sisi pendapat mengenai hukum sholat jamak dan qasar yang berlaku bagi umat Islam yang akan melakukan perjalanan jauh atau safar. Imam Hanafi seorang musafir diperbolehkan jamak serta qasar sholat bukan terletak pada jarak perjalanan, melainkan pada batasan waktu perjalanan. Sedangkan menurut Imam Syafi'i seorang musafir dapat mengambil keringan shalat ini jika telah memenuhi jarak tertentu.

Menurut penulis, penulis cenderung kepada pendapat Imam Syafi'i, karena pemikiran Imam syafi'i cenderung lebih fleksibel dan mudah dikerjakan disaat sedang melakukan perjalanan atau safar.

\section{KESIMPULAN}

Pendapat Imam Hanafi dan Imam Syafi'i tentang Sholat Jamak dan Qasar bagi musafir adalah sebagai berikut: pertama, pandangan Imam Hanafi tentang jamak dan qasar bagi musafir. Hukum melaksanakan jamak ialah tidak diperbolehkan. Sedangkan hukum melaksanakan qasar ialah fardhu 'ain atau wajib tidak diperbolehkan melakukan sholat secara sempurna. Dalam shalat qasar Imam Hanafi menghitungnya menggunakan hari dan meniadakan niat tertentu untuk melaksanakannya. Masa berlakunya jamak 
dan qasar ialah 15 hari. Apabila tidak menetap dan masih melanjutkan perjalanan ialah 3 hari.

Kedua, pandangan Imam Syafi'i tentang jamak dan qasar bagi musafir. Beliau berpendapat bahwa jamak shalat hukumnya boleh, baik itu jamak taqdim atau jamak ta'khir. Selain keadaan safar Imam Syafi'I juga memperbolehkan jamak shalat dalam keadaan hujan. Sedangkan hukum sholat qasar ialah jaiz (boleh), memilih antara mengqasar shalat atau itmam (menyempurnakan 4 rakaat) tetapi menurut beliau menyempurnakan sholat lebih utama. Niat qasar harus dilakukan untuk setiap kali shalat dan dilakukan ketika takbiratul ihram. Imam Syafi'i juga mengisyaratkan jenis safar yang diperbolehkan untuk mengqasar shalat yakni safar yang mubah bukan safar yang bertujuan maksiat. Karena tidak boleh untuk mengqasar shalat dan kalau dilakukan maka shalatnya tidak sah. Bagi seorang musafir yang berdomisili di suatu tempat tanpa niat selama 4 hari 4 malam dan tidak menetukan waktu perjalanan, maka tetap diperbolehkan melakukan dispensasi qasar selama 18 hari 18 malam.

Ketiga, perbandingan pandangan Imam Hanafi dan Imam Syafi'i tentang shalat jamak dan qasar bagi musafir. Hasil komparasi dua pendapat tersebut menurut penulis apabila seorang musafir berniat melakukan shalat jamak maka, penulis cenderung kepada Imam Syafi'i, karena untuk melaksanakan rukshah shalat jamak bisa dilakukan tanpa harus di Arafah dan Muzdhalifah. Tanpa terikat dengan tempatnya. Jadi ketika seorang musafir melakukan perjalanan dengan niat dan tujuan yang baik, maka boleh melaksanakan shalat jamak. Apabila seorang musafir melaksanakan shalat qasar, penulis cenderung kepada Imam Syafi'i karena adanya kebebasan untuk memilih antara mengqasar ataupun menyempurnakan 4 rakaat. Karena adakalanya seorang musafir melakukan shalat dengan cara sempurna bisa digunakan untuk beristirahat setelah perjalanan jauh. 


\section{REFERENSI}

A Rahman I, Doi, Karakteristik hukum Islam, alih bahasa Zaruddin, cet 1, Jakarta: Raja Grafindo Persada, 1996.

Abu Zahrah, Muhammad, asy- Syafi'i, hayatuhu Wa'asruhu ar Ro'uhu wa fiquhu, Mesir: Dar al- Fikr al Arabi, t.t.

Al Bukhori, Imam Muhammad Ibn Ismail, Shahih Bukhari, Beirut: dar AlFikr, t.t.

Al Ghazali, Muhammad, Karakter Muslim, Bandung: Risalah 1987.

Al Nasa'iy, Abu Abdurrahman Ahmad, Sunan al-nasaiy, Beirut: Dar alKutub al 'Alamiyah, 1999.

Ash Shidiqiey, TM. Hasbi, Falsafah Hukum Islam, cet 3, Jakarta: Bulan Bintang, 1998.

1958. , Pedoman Shalat, cet 13, Jakarta: Bulan Bintang,

\section{3.} , Pengantar fiqih, cet 8, Jakarta: Bulan Bintang,

Asy, Syurbasi, Ahmad, Sejarah dan Biografi Empat Imam Mazhab alih bahasa Sabil Huda dan A. Ahmadi, Cet 2, Jakarta: Bumi Aksara, 1993.

Bahri Ghozali dan djumadris, Perbandingan mazhab, Jakarta: Pedoman Ilmu Jaya, 1996.

Departemen Agama, Al-Qur'an dan terjemahnya, Jakarta: Proyek Pengadaan Kitab Suci Al-Qur'an, 2006.

Direktorat Pembina Pergururuan Tinggi/ IAIN, Pengantar Ilmu Fiqih (Pengantar Ilmu Hukum Islam), Jakarta: t.p,1981.

Hadi Sutrisno, Metodologi Research, Cet 28, Yogyakarta: Andi Offset, 1995. Huzaemah Tahida Yanggo, Pengantar Perbandingan Mazhab, Jakarta: Depag RI, 1993.

Ibnu Hanbal, Ahmad, Musnad, Beirut: Dar Al-Fikr,1987.

Manan, Abdul, Fiqih LintasMazhab, Kediri: t.p., t.t.

Mughniyah, Muhammad Jawad, Al- Figh 'Ala Al-Mazahib Al- Khamsa, Beirut: Dar Al-Ilmi, 1973.

Muslim, Sahih Muslim, Beirut: Dar Al-Fikr, t.t.

Nasution, Lahmudi, Fikih Ibadah, cet. 11, Jakarta: Logos Wacana Ilmu. 1999.

Qardawi, Yusuf, Dasar Pemikiran Hukum Islam Taqwa Ijtihad, ali9h bahasa Husein Muhammad, Jakarta: Pustaka Firdaus, 1997.

Qardawi, Yusuf, Dasar Pemikiran Hukum Islam, Taqwa Ijtihad, Husein Muhammad, Jakarta: Pustaka Firdaus, 1987.

Qutub Muhammad, Konsep Ibadah Dalam Membentuk Generasi Qur'ani, Abu Fahmi, cet 2, Jakarta: Gema Insani Press, 1992.

Sabiq, As-Sayyid, Fiqih As-Sunnah, Beirut: Dar Al-Fikr, 1981. 
Sirry, Mun'im A, Sejarah Fiqih Islam, cet 1, Surabaya: Risalah Gusti, 1995. Syaltout, Syaikh Mahmoud, Perbandingan Mazhab Dalam MAsalah Fiqih, Cet 8, Jakarta: Bulan Bintang, 1996.

Syamsudon, Asy-Syarkhasi, Al- Mabsut, Beirut: Dar Al- Maifah, 1989.

Winarno, Surachmad, Pengantar Penelitian Ilmiah Dasar Metode Teknik, Bandung: Tarsito, 1980. 